ks. Paweł Murziński

Papieski Wydział Teologiczny w Warszawie

DOI: 10.15290/std.2017.03.08

\title{
KONCEPCJA NADPRZYRODZONOŚCI W SYSTEMACH RELIGIJNYCH WSCHODU (AZJI) I ICH RECEPCJA NA ZACHODZIE (USA I EUROPA) NA GRUNCIE ŚWIATOPOGLĄDU NEW AGE
}

\author{
THE CONCEPTION OF SUPERNATURALISM \\ IN RELIGIOUS SYSTEMS OF THE EAST (ASIA) \\ AND THEIR RECEPTION IN THE WEST (THE USA \\ AND EUROPE) BASED ON IDEOLOGY OF NEW AGE
}

Present article aims at showing the supernaturalism conception of religious systems of the East against the background of Christian supernaturalism conception based on the Word of God and the conception of New Age Movement which is built on worldview of religious systems of the East. The base of this conception differs from the Christian one. It is a pantheist delineation of God, so it assumes there is no real border between Him and creature. This fact changes perception of character of the creation and idea of spirituality diametrically. Because this delineation premises an emanation of divinity, not the act of Creation without violation of the essence of God, it does not mention about the real identity of human being, Divine Mercy, or eternal life at all. For humane-self is illusive and Wight is coming up for process of consecutive reincarnations, which are dependent on karma. Ergo, spirituality of the East does not base on right of reprieve and techniques that are associated with the spirituality are peculiarly gnostic, connected with enlightenment of mind and nirvana, explained by entrants of New Age as stifling or transformation 
of perceptorium. These ideas have been present in western notion starting from ancient Greek thought through Jewish kabbalah, Christian Gnosticism, esotericism, illuminism, theosophy, anthroposophy and so-called potential of human's mind development characteristic of New Age's praxis. On the other hand, transcendental meditation, yoga, reiki or martial arts base on idea of socalled divine qi energy which with suitable techniques, poises, or meditation you can tap inside you or be fulfilled with to get specified benefits, therapic powers, inner harmony, etc. It is a cosmic delineation of God regarded as macrocosm and human regarded as a microcosm defined as a hologram of surrounding reality. What is more, according to religious systems of the East and New Age Movement, human is regarded as a small piece of divine mind and direct emanation of god. They need no God's Epiphany, tenets, or religious system which would make knowable reality objective or would mediate between them and God. From the viewpoint of this world's vision, there can't be any objective truth, because everyone is in possession of it proportionately to their enlightenment. Hence cognitive relativism ant toleration towards different opinions or religious systems, for ultimate instance in this perception of God and the world is only Wight, not Epiphany or any religious authority. .

Key words: God, eternity, supernatural, spirituality, meditation, divine Energy, gnosis, evolution, creation, emanation, eternal life, pantheism, transcendent, law of karma, illusion, esoteric psychology, biotherapy, transformation of consciousness, Absolute, reincarnation, mind of the universe, relativism.

\section{Wstęp}

Pojęcie nadprzyrodzoności samo w sobie zakłada istnienie rzeczywistości ponad czy poza. Może ono zakładać jej nieskończone rozmiary bądź zamknąć w przestrzeni wszechświata. Może stawiać granice nieprzekraczalne przez ludzką naturę bądź dawać nadzieję stania się Boskim jak to ma miejsce np. w systemach religijnych Wschodu. Może prowadzić do uznania panowania Boga i posłuszeństwa wiary, a może prowadzić do chęci manipulowania tą rzeczywistością jak to ma miejsce w magii. Może chcieć udowodnić jej nieistnienie, by postawić człowieka w centrum wszystkiego, a może widzieć potrzebę Boga jako celu ostatecznego i absolutnego źródła Prawdy, Dobra i Piękna. Może też zakładać Jego istnienie bez chęci podporządkowania się Bożemu Prawu, właściwe dla ateizmu praktycznego, na który wskazywał wyraźnie św. Jan Paweł II jako na problem współczesnego kryzysu wiary. Jest to w końcu próba pogodzenia kreacjonistycznej i ewolucyjnej wizji rzeczywistości w dialogu nauki i wiary 
bądź też znalezienia takiego systemu religijnego, który by ewolucyjną wizję nauki zakładał i wyjaśniał. Takim systemem jest właśnie ten właściwy systemom religijnym Wschodu, zawierający emanacyjną wizję Boga i świata. New Age jest w istocie produktem fuzji, jakiej dokonano łącząc emanacyjną wizję religii Wschodu z tą właściwą współczesnej fizyce i astronomii. W konsekwencji stajemy dziś wobec zupełnie nowego światopoglądu, dającego nam całkowicie inną wizję Boga, świata i człowieka, a zatem także odmienne rozumienie nadprzyrodzoności, nieskończoności, transcendencji i duchowości. To nowe rozumienie wypływa z mentalności kultury, która poprzez nowożytność (w niej chciała uwolnić się od dyktatu wiary), doszła do postmodernizmu, w którym zawiedziona rozumem szuka trzeciej drogi i znajduje ją w tym, co jest na poły religijne, a na poły magiczne i naukowe.

\section{Idea Boga}

Idea nadprzyrodzoności zakłada istnienie rzeczywistości, która przekracza człowieka we wszystkich wymiarach jego przyrodzonej egzystencji. Idea ta może być bądź owocem bezpośredniego objawienia się Boga bądź też owocem poszukiwań ludzkiego rozumu i osobistego doświadczenia wewnętrznego. W tym drugim przypadku nadprzyrodzoność jest niejako zamknięta w granicach ludzkiego poznania, a granica pomiędzy tym, co ludzkie a tym, co Boskie, wyraźnie się zaciera. Tak rozumiana sfera nadprzyrodzoności jest właściwa dla wielkich systemów religijnych Wschodu, jak również dla wizji New Age, która dokonuje ich recepcji na gruncie kultury Zachodu. Niepełność tej wizji i światopoglądowe tego konsekwencje są widoczne dopiero w konfrontacji z religią Objawioną, która wychodzi od faktu Objawienia do zrozumienia rzeczywistości, a nie od analizy własnego ja i otaczającej nas rzeczywistości. Analiza ta zatrzymuje się na granicy wszechświata wyznaczonej przez czaso-przestrzeń, dopowiadając sobie to, co dla nas jest objawione. Wynik jednak dociekań myśli ludzkiej widoczny w hinduizmie czy buddyzmie, bo te nas najbardziej interesują, jest zgoła inny od perspektywy, jaką daje nam Objawienie. W religiach objawionych u początku stworzenia jest Bóg, Stwórca nieba i ziemi ex nihilo. Tymczasem w systemach religijnych Wschodu u początku stworzenia nie ma nic. Jest Bóg niejako w niebycie i dlatego tam akt stwórczy świata jest tożsamy z ukazywaniem się kolejnych doskonałości Boga. W ten sposób nie istnieje w tych systemach realna różnica pomiędzy Bogiem a światem, gdy tymczasem w naszej wierze świat jest odbiciem Boskich doskonałości, ale boski ontologicznie nie jest. Ten „niebyt” Boga można określić jako stan nirwany, kosmicznego jaja, z którego wyłania 
się bóstwo emanując wszystkie swoje właściwości ${ }^{1}$. U granic wszechświata zatem Wschód dostrzega ex nihilo, z którego wyłania się nasza rzeczywistość. Wiara polegająca na Objawieniu się Boga poszerza nieskończenie ten horyzont o łaskę poznania Boga Stwórcy, na którego podobieństwo jesteśmy stworzeni. Widzimy więc, że idea Boga w systemach religijnych Wschodu pozbawiona jest realnej transcendencji, co rzutuje na wszystkie inne sformułowania „dogmatyczne” i „moralne” tych systemów. Mamy więc w efekcie do czynienia $z$ dwoma odmiennymi światopoglądami. Jeżeli wiec niektórzy utrzymują, że wszystkie drogi prowadzą do Boga, to należałoby się zapytać: ale do jakiego boga? Ta odmienna idea Boga wpisuje się ponadto w dyskusję, jaka toczy się pomiędzy kreacjonistyczną i ewolucjonistyczną koncepcją stworzenia, która na gruncie wiary opiera się właśnie na idei Boga.

\section{Idea Boga a koncepcja stworzenia}

Zgodnie z koncepcją religijną Boga, który jest, ale niejako w potencji stwórczej, a „staje się” w procesie emanacji siebie, powstaje ewolucyjna koncepcja zaistnienia bytu, który emanuje się, czy zgodnie z nam bliższą terminologią, ewoluuje się w czaso-przestrzeni². Dziś próbuje znaleźć się wspólny mianownik pomiędzy ideą stworzenia z niczego a koncepcją ewolucji rozumiejąc akt stwórczy Boga jako początek procesu ewolucji, która jest rozumiana jako kontinuum stwarzania. Czy tak jest rzeczywiście? Czy świat jest raz stworzony i utrzymywany wolą Stwórcy czy też wciąż ewoluuje, a wraz z nim człowiek? Od tej odpowiedzi zależy także rozumienie rzeczy ostatecznych. Jeżeli zgodnie $z$ myślą systemów religijnych Wschodu rozumiemy stworzenie jako emanację bóstwa w czaso-przestrzeni, to nie w niej miejsca na nieskończoność i życie wieczne jako rzeczywistość definitywną. Stoimy raczej przed niekończącym się cyklem kolejnych emanacji, rozwijania i zwijania się wszechświata w swoich kolejnych manifestacjach. Pismo Święte i nauka Kościoła widzą natomiast akt stwórczy jako dokonany, a naturę ludzką jako niepodlegającą zmianie, co nie

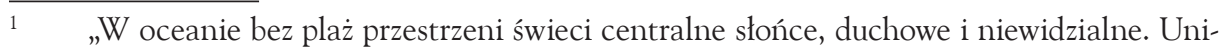
wersum jest jego ciałem, jego duchem i jego duszą; na tym idealnym modelu opierają się wszystkie inne rzeczy. Niewidzialny przyjmuje formę, kiedy powołuje świat do egzystencji”. H. P. Blavatsky, Iside Svelata. Chiave dei misteri della scienza e della teologia antiche e moderne, vol. I: Scienza, Milano 2000³, s. 330.

2 Francesca Drago mówi o religiach Wschodu jako o „kamieniu filozoficznym” i o „bramie niebios” umożliwiającej przejście w inną rzeczywistość, gdzie „działają niewidzialne energie, na których opiera się stworzenie”. Zmysłowa iluzja bycia w czasoprzestrzeni doświadczana przez klasyczną naukę jest więc „oszustwem”, które utrzymuje człowieka w opacznie pojmowanej materii i nie pozwala mu przenikać Duchowej Rzeczywistości. F. Drago, Vivere New Age, Milano 19981', s. 62. 
miałoby sensu, gdyby człowiek jako część natury, podlegał wraz z nią jakiejś ewolucji, nie tylko na poziomie biologicznym, lecz również mentalnym i duchowym. Są owszem tacy, którzy chcieliby w sześciu dniach stworzenia odnaleźć poszczególne etapy ewolucji, ale niestety ten opis nie jest opisem postępującego rozwoju stworzenia. Ukazuje on bowiem trzy sfery: morze, niebo i ziemię, które są następnie wypełniane przez konkretne formy bytów. Nie jest to zatem biblijny dowód na ewolucję. Zapowiedziane nowe niebo i nowa ziemia nie są zatem wynikiem dokonanego postępu czy ewolucji, ile odnowieniem stworzenia takiego, jakie było odwiecznie w zamyśle Boga. Otwarcie się Kościoła na teorie naukowe nie mają więc na celu „ochrzczenia” teorii ewolucji bądź godzenia na siłę zwolenników kreacjonizmu i ewolucjonizmu, ale są otwarciem na dialog pomiędzy dwoma władzami poznawczymi, jakimi są nauka i wiara, wykazując, że sprzeczności pomiędzy nimi, jeżeli są, to są pozorne i będą w raz z rozwojem nauki przełamywane, aż do punktu, w którym spotkają się ze sobą ukazując Boga tożsamego dla wiary i nauki.

\section{Idea życia wiecznego}

W świetle naszej wiary, nadprzyrodzoność jest rzeczywistością, która jest $z$ natury rzeczy nieosiągalna dla człowieka. Wierzymy też, że stajemy się uczestnikami tej rzeczywistości poprzez akty Wcielenia i Odkupienia człowieka, a wraz z nim całego stworzenia. Natomiast idea Boga „stającego się” poprzez emanację nie dopuszcza realnego rozróżnienia na to, co przyrodzone i na to, co nadprzyrodzone. Można rzec, że zgodnie z tą rzeczywistością nie ma przejścia od przyrodzonego do nadprzyrodzonego, ale jest osiąganiem, stawaniem się, coraz bardziej Boskim. To wyklucza z kolei koncepcję życia wiecznego rozumianego jako rzeczywistość definitywną, którą osiąga się drogą łaski, nawet jeśli zakłada ona również konieczność rozwoju duchowego, to nie jest on sam w sobie warunkiem Zbawienia, czego przykładem może być choćby Dobry Łotr. Koncepcja emanacyjna zakłada bowiem pewien postępujący proces rozwoju, od którego uzależniona jest przyszłość człowieka. Śmierć jednak nie wyznacza wcale w tej wizji granicy czy kresu tego procesu. Jest on właściwie nie do określenia w emanacyjnej koncepcji świata. Stąd rodzi się koncepcja reinkarnacji, czyli potrzeby kolejnych wcieleń ${ }^{3}$. Życie wieczne nie jest bowiem zależne od prawa łaski lecz

3 „Człowiek jest ukazany przez ruch Nowej Ery jako wieczny i wolny duch, który wybiera, $\mathrm{w}$ jaką szczególną relację z systemem solarnym wejść, wcielając się i przyjmując $\mathrm{w}$ ten sposób obowiązek ukazywania swojej boskości w każdym podejmowanym działaniu. Uwolniony od obsesji swojej osobowości i dramatu śmierci, zostaje wchłonięty przez nieskończoność. Ale to całkowite unicestwienie - biorąc pod uwagę kategorię czasu może stać się punktem wyjścia dla nowej przygody podobnego typu dzięki reinkarnacji”. M. Introvigne, Il cappello del Mago, Milano 2003, s. 272. 
od doskonałości człowieka, której nie da się osiągnąć w ciągu jednego życia, ale poprzez cały cykl wcieleń, kiedy to człowiek zgodnie z prawem karmy musi sam dopełnić miary sprawiedliwości aż do punktu, kiedy będzie mógł połączyć się z Jednią, z której wyemanował. Łaska bowiem zakłada istnienie osobowego Boga i relację miłości, jaka łączy Stwórcę ze swoim stworzeniem. Ta relacja w systemach religijnych Wschodu nie zachodzi. Pozostaje jedynie zależność przyczynowo-skutkowa leżąca u podstaw prawa karmy. Nie ma w niej miejsca na Odkupienie. Wszystko zależy od postępowania człowieka zgodnie z zasadą: jak się pościelesz, tak się wyśpisz. Nie ma zatem miejsca na przebaczenie. Niebo w konsekwencji traci swój charakter nadprzyrodzony, gdyż jego osiągnięcie nie jest dziełem łaski, lecz wyłącznie wysiłku człowieka.

\section{Praktyki duchowe}

Duchowa łaska jest rzeczywistością dla człowieka wierzącego, rzeczywistością nadprzyrodzoną i nie można jej sobie wypracować i chociaż stan duchowy człowieka nie jest obojętny co do przyjęcia łaski, to sama w sobie pozostaje niezasłużonym i niemożliwym do wypracowania dla człowieka darem. Inaczej rzecz się ma z „duchowością” Wschodu. Opiera się ona na tzw. technikach medytacji, których skuteczność jest zależna od zaawansowania osoby medytującej, a nie od woli Bożej, gdyż tej tzw. boska energia nie posiada. Są one w swej istocie magiczne, gdyż inicjatywa w nich należy do człowieka, a nie do bezosobowej energii, która staje się źródłem mocy, wewnętrznej harmonii, oświecenia i gwarantem osiągnięcia stanu tzw. nirwany. Stan ten jest powrotem naszego ja do boskiej Jedni i rozpłynięciem się naszej tożsamości, co stoi w sprzeczności ze stanem wiecznego odpoczynku w Bogu Stwórcy. Jako że w religiach Wschodu nie mamy do czynienia z osobowym Bogiem w naszym rozumieniu, gdyż przed „stawaniem się” istnieje on niejako w swojej Jedni, $z$ której emanuje, jest on rozumiany jako Umysł wszechświata, utrzymujący wszystko w harmonii. Zaburzenie tej harmonii poprzez niestosowanie się do prawa natury powoduje zaburzenie tej harmonii zarówno w człowieku jako mikrokosmosie jak i we wszechświecie jako makrokosmosie. Przywrócić ten porządek można poprzez wyjście z prawa karmy i przez stosowanie technik medytacji. W tej perspektywie nie ma miejsca także na istnienie osobowego zła i grzechu, gdyż człowiek jako cząstka Boskiego umysłu odchodzi od Boskiego prawa na skutek błędu a nie zdeprawowanej woli. Potrzebuje zatem oświecenia a nie nawrócenia ${ }^{4}$. W tej perspektywie religie Wschodu możemy uznać za

4 „Ja jestem tą wyższą cząstką ciebie samego, która pulsuje w twoim wnętrzu, która odpowiada na moje słowa, przeczuwa prawdę, rozpoznaje ją całą ze swej natury i przezwycięża każdy błąd jakikolwiek napotka. Tym właśnie Ja jestem: nie tą cząstką ciebie, która aż 
pewną formę gnozy. Na podstawie powyższych przesłanek możemy też jasno wykazać, że systemy religijne Wschodu są z gruntu panteistyczne. Ten brak realnej granicy pomiędzy Bogiem a stworzeniem sprawia, że trudno jest mówić również o realnej koncepcji nadprzyrodzoności. Człowiek ze swej natury jest bowiem Boski, jak również otaczający go świat. Traci w sobie jednak przez łamanie boskiego prawa pełnię boskiego ducha, z którym nie może się zjednoczyć dopóki poprzez moralne życie i techniki medytacji nie osiągnie znowu swojego pierwotnego stanu. To jest ich raj utracony, całkowicie odmienny w swych założeniach od naszego.

\section{Boom duchowości wschodniej i guru-przewodnicy pod etykietą New Age}

We współczesnej kulturze Zachodu obserwujemy wyraźny kryzys chrześcijaństwa. Jest on wynikiem laicyzacji społeczeństwa, a także dominującego w tejże kulturze utylitaryzmu i hedonizmu. Ateizacja społeczeństwa okazała się wszakże niemożliwa, gdyż nie była w stanie zgasić w człowieku pragnienia nadprzyrodzoności. Zaczęto zatem poszukiwać alternatywy we wszelkiego rodzaju innych wierzeniach i tworzyć substytuty wiary, aby zapełnić pojawiającą się pustkę duchową. Na pierwszy plan wysunęło się wyraźne zainteresowanie systemami religijnymi Wschodu, ze swoją spójną wizją oraz technikami medytacji zapewniającymi żywe doświadczenie przekraczania siebie i poczucie odzyskania utraconej harmonii. To gwałtowne zapotrzebowanie na nową duchowość przerodziło się w efekcie w tendencję określaną jako „boom duchowości wschodniej”, inwazja Wschodu bądź pseudoorientalizacja Zachodu 5 . To ostatnie określenie wydaje się najwłaściwsze, gdyż recepcja wprost całego światopoglądu z jego wymogami okazała się niemożliwa. Na ogół przyjmuje się tylko pewne formy medytacji, yogi, wierzeń np. w reinkarnację, często modyfikując je i adaptując do mentalności i warunków życia człowieka Zachodu. Dokonuje się to właśnie na bazie fenomenu określanego jako New Age, który w znacznej mierze opiera się w swoich założeniach i praktykach na myśli systemów religijnych Wschodu. Pierwsi guru przybyli „ewangelizować” Zachód

do dziś żyła w ignorancji. Ponieważ Ja jestem twoim prawdziwym Mistrzem, jedynym którego będziesz znał zawsze, twoją boską Sobością". Conte di Saint-Germain, Io Sono, L'Età dell'Acquario, 2001', maj 2006, s. 12.

5 „Rewolucja młodych lat 60' XX wieku rodzi też nowe idee: pacyfizm, powrót do natury (ekologia głęboka), a także nowe poczucie sacrum: ekofeminizm (Matka Natura) oraz poszukiwanie «boga wewnętrznego». Powstają «naturalne» wspólnoty, które jednak coraz częściej padają lupem guru, «ludzi-bogów» przybywających ze Wschodu. Zatem złote lata rewolucji młodych kończy ostatecznie tzw. boom guru". E. Pigani, Channel. I medium della Nuova Era, Roma 1993, s. 165-167. 
szybko zauważyli, że trzeba dostosować terminologię i przekaz wiedzy oraz stosowane praktyki do mentalności innej kultury. Recepcja ta dokonuje się więc zarówno na płaszczýnie światopoglądowej jak i praktycznej, odnoszącej się do sfery duchowości i stylu życia współczesnego człowieka Zachodu.

\section{Tao fizyki}

Jedną ze sztandarowych postaci związanych z Ruchem Nowej Ery jest Fritjof Capra. Dostrzegł on i opisał podobieństwa pomiędzy emanacyjną wizją Boga w wielkich systemach religijnych Wschodu a tym, jak ukazuje nam wszechświat i jego genezę współczesna fizyka i astronomia. Swoje spostrzeżenia umieścił w książce o znamiennym tytule Tao fizyki. Innym jego ważnym dziełem odnośnie powiązań fizyki z religijnymi koncepcjami Wschodu był Punkt zwrotny ${ }^{6}$. Było to jego swoiste wyznanie wiary, że to właśnie ta wizja rzeczywistości, a nie biblijna jest prawdziwa. Teorie Wielkiego Wybuchu i ewolucji kosmosu, które są obecnie powszechnie obowiązujące, wykazują bowiem zasadniczą zbieżność $z$ wizją powstawania wszechświata jako emanacji bóstwa ze stanu wyklucia się ze swoistego kosmicznego jaja właściwą dla systemów religijnych Wschodu. Jest to zatem wizja panteistyczna niepozostawiająca miejsca dla Boga Stwórcy i w konsekwencji zacierająca realną różnicę pomiędzy Bogiem a światem? Pozbawia tym samym Boga realnej transcendencji właściwej chrześcijaństwu. Stąd „duchowość” systemów religijnych Wschodu możemy wziąć w cudzysłów, gdyż nie prowadzi ona do osobowego spotkania człowieka z Jego Stwórcą, ale uzależnia skuteczność praktyk „duchowych” od właściwego i cierpliwego powtarzania określonych technik. Boska energia ki pojawia się w „medytacjach” Wschodu, yodze, reiki, sztukach walki. Leży u podstaw filozofii życia. Na gruncie kultury Zachodu pojawia się jako znana dziś powszechnie bioenergoterapia i wszelkiego rodzaju Bio, które towarzyszy produktom i metodom nie tylko związanym z ekologią, ale również ze sferą okultyzmu.

6 „Mamy dziś szczególną potrzebę nowego paradygmatu, nowej wizji rzeczywistości, fundamentalnej zmiany sposobu myślenia, postrzegania świata, a także nowego systemu wartości. Początki tej epokowej zmiany, czyli przejścia od tradycyjnej, mechanistycznej koncepcji świata do tej holistycznej, są dziś widoczne na wszystkich płaszczyznach życia człowieka”. F. Capra, Il Punto di Svolta, Milano 1984, s. 42.

7 „Ów ocean energii ukazuje się nam jakojeden żywy organizm, zawierający całą rzeczywistość czy to «materialną», czy «duchową». Z takiej perspektywy materia i energia postrzegane są jako dwa aspekty tej samej praprzyczyny bytu, uniwersalnej Wibracji, którą można by nazwać naukową koncepcją panteistycznego Boga”. A. N. Terrin, New Age. La religiosità del postmoderno, Bologna 1993', 1997², s. 96. 


\section{Biocentryczna wizja świata a terapie „bio”}

Panteistyczna wizja Boga właściwa dla systemów religijnych Wschodu jest przyjęta w światopoglądzie New Age, opartym na ewolucyjnej wizji świata właściwej dla New Science, jako wizja biocentryczna. Dlatego Bio stanowi obecnie słowo wytrych, które jest podkładką dla wielu metod i produktów nie mających często nic albo niewiele wspólnego ze znaczeniem tego słowa. Klasycznym tego przykładem jest tzw. bioenergoterapia. Ludzie zajmujący się nią nazywają siebie bioenergoterapeutami i przypisują sobie nadzwyczajne zdolności wypływający z faktu posiadania przez nich rzekomo pochodzącej od Boga szczególnej energii o leczniczych właściwościach ${ }^{8}$. Ten rzekomy „dar” stoi jednak w opozycji z założeniami naszej wiary. Zgodnie z nią, uzyskanie zdrowia przez człowieka w sposób cudowny jest dziełem cudownej i suwerennej interwencji Boga, która jest w niczym niezasłużoną łaską, w dodatku uzależnioną od stanu duchowego człowieka i od jego wiary. Nie ma możliwości wspólistnienia czy pogodzenia ze sobą tych dwóch rzeczywistości, jakimi są łaska i bioenergia czy też boska energia, bo o taką ostatecznie chodzi, nawet jeśli wprost się jej tak w bioenergoterapii nie nazywa. Jest ona jednak lustrzanym odbiciem wschodniej terapii znanej jako reiki, czyli w tłumaczeniu energia, która leczy. Jej posiadaczem zgodnie z koncepcją wschodnią jest każdy, tylko trzeba ją z siebie wydobyć i nauczyć się nią posługiwać. Nie jest więc ona w założeniach systemów religijnych Wschodu, jak chcieliby niektórzy, tylko dla wybrańców losu. Jest to więc założenie z gruntu magiczne, gdyż nie wymaga ono ani wiary, ani osobowej interwencji Boga, ani liczenia się z Jego wolą. Tu „panem posiadanej mocy”, w tym wypadku bioenergii, jest człowiek. Również osoba podlegająca „leczeniu” nie musi spełniać żadnych warunków duchowych jak wiara, stan łaski uświęcającej czy nawrócenie. Dziś coraz więcej terapii i produktów jest sprzedawanych pod „magiczną” nazwą Bio i wielu z nich faktycznie jest okultystyczna. W chrześcijaństwie to, co nadzwyczajne zawsze jest dziełem łaski, jest darem. Nawet dary nadzwyczajne nie wynikają wprost z predyspozycji człowieka ani nie stają się Jego własnością. Nawet nadużywane są domeną Boga. Żaden chrześcijanin posiadający charyzmat uzdrawiania nie określa się jako uzdrowiciel i nie od niego zależy to czy i kto będzie uzdrowiony. Dzieje się tak dlatego, że zgodnie z Objawieniem istnieje realna, wyraźna i nieprzekraczalna granica pomiędzy tym, co stworzone i niestworzone oraz

8 „New Age redukuje wymiar boski i duchowy bytu do poziomu kosmicznej Energii, koncepcji uformowanej dzięki wpływowi hinduskiego panteizmu eterycznego (według którego na uniwersum składa się znajdujący się w stadium emanacji boski eter) i współczesnej fizyki”. M. Guerra, Satanizm i lucyferyzm jako alternatywna i magiczna forma religijności naszych czasów, [w:] Teologia o Szatanie, Międzynarodowe sympozjum odbyte na Katolickim Uniwersytecie Lubelskim w 2000, K. Góźdź (red.), Lublin 2000, s. 83. 
pomiędzy tym, co przyrodzone i nadprzyrodzone. Tej realnej różnicy nie ma ani w wielkich systemach religijnych Wschodu, ani w praktykach New Age ani we współczesnej wizji ewolucji kosmosu. Przenika tu wszystko wszechogarniająca energia bądź boskie eony będące w procesie ciągłej ewolucji. Również człowiek podlega temu procesowi. Wschodnia anima nie jest więc tym samym co dusza w rozumieniu chrześcijańskim. Tworzy ona w człowieku ciało energetyczne bądź astralne, które zawiera w sobie potencjał energii, którą można wydobyć poprzez medytację transcendentalną, yogę, reiki czy sztuki walki jak np. ai-ki-do.

\section{Ewolucjonizm jako kontinuum stworzenia}

Zgodnie z zasadą ewolucji akt stwórczy jest wykluczony lub ogranicza się do rozpoznania w Bogu zasady sprawczej procesu ewolucji. Ta próba dostrzeżenia w ewoluującej rzeczywistości ręki Stwórcy prowadzi do uznania tego procesu jako kontinuum stworzenia. Kłóci się to z biblijną wizją definitywnego aktu stworzenia przez Boga, który na początku stworzył niebo i ziemię i napełnił je wszelkimi bytami. W tej wizji nie ma zasadniczo miejsca na ewolucję, chyba że przyjmiemy, iz to właśnie ta zasada sprawcza, dała początek ewolucji nieba i ziemi, i bytów je wypełniających. Z punktu widzenia wiary chrześcijańskiej niezależnie od faktu czy będziemy mówić o jednorazowym i definitywnym akcie stwórczym Boga czy też o Bogu jako przyczynie sprawczej ewolucji, będziemy mieli do czynienia z Bogiem osobowym, różnym od świata i panującym nad swoim stworzeniem, czy to bezpośrednio czy poprzez nadane naturze Prawa. Natomiast w wizji systemów religijnych Wschodu sam Bóg emanując siebie i swoje doskonałości znajduje się w ustawicznym procesie stwórczym. Jest to zatem ewolucyjna wizja Boga, a zarazem wizja panteistyczna. Bóg w niej nie tylko nie jest różny od świata, ale to On sam nim jest ${ }^{9}$. Wszystko więc co istnieje i co uważamy za odrębne byty jest w rzeczywistości maya czyli iluzja, bowiem w tej wizji istnieje realnie tylko jeden Byt, a stworzenie jest emanacją Jego właściwości ${ }^{10}$. W wizji chrześcijańskiej natomiast Bóg transcenduje stworzoną

9 „Bóg transcendentny tradycji chrześcijańskiej, przekraczający granice stworzenia, staje się Bogiem immanentnym, który przenika wszystko, ale poza to wszystko nie wykracza. Taki Bóg, według Johna Price’a, jest uniwersalną Jaźnią, a nie zwykłym odzwierciedleniem stworzenia czy bytem odseparowanym od niego. Poza Bogiem bowiem nic nie istnieje, ponieważ wszystko jest Bogiem”. J. R. Price, Il Codice di Gesù. Un'esperienza mistica rivela un nuovo paradigma per la vita, Diegaro di Cesena 2001', s. 15.

10 „Dualistyczna natura wszechświata nie istnieje w Świecie Realnym. Nie istnieje zdrowie czy choroba, dostatek czy niedostatek, pokój czy konflikt. Bóg Jest, jedyny Ojciec, nieskończony i wszechobecny Duch. Wszystko inne to maya, iluzoryczna rzeczywistość projektowana przez nasz umysł, która może być oceniania jako dobra bądź zła zależnie od obserwatora". Ibidem, s. 105. 
przez siebie rzeczywistość, a byty przez Niego stworzone są realne, choć zależne w swym istnieniu od Boga Stwórcy.

\section{Transformacja świadomości a ewolucja człowieka}

Miłość i miłosierdzie nie są obce ludziom Wschodu ani ich kulturze. Doświadczenie miłości nie wypływa niestety u nich z ich osobowej relacji z Bogiem, ale $z$ doświadczenia życia. Ich wizja kosmicznego Boga w ewolucji i duchowość będąca otwieraniem się na harmonię i boską energię wyklucza osobową wizję Boga, który jest Miłością. Skutkiem tego jest właśnie prawo karmy, będące odzwierciedleniem czystej kosmicznej sprawiedliwości niepozostawiającej miejsca na przebaczenie, łaskę i miłosierdzie. To, co dostrzegają we wszechświecie, to myśl stojącą za harmonią kosmosu i niezmienność kierujących nimi praw, za którymi widzą tzw. Umysł Wszechświata ${ }^{11}$. Na tej podstawie nie można, niestety, stworzyć osobowej wizji Boga, z którym możemy wejść w relację miłości. Zresztą w tej panteistycznej wizji sam Bóg jest niejako zdeterminowany ewoluować się zgodnie z prawami ewolucji, których źródłem jest, ale też którym jest poddany nie będąc ponad nimi i poza nimi. A determinizm, siłą rzeczy, wyklucza wolną wolę. Bóg w tej wizji nie stanowi zatem nieodgadnionego Misterium, którym jest i pozostanie w naszej wierze pomimo faktu Objawienia. Jest Bogiem ograniczonym granicami kosmosu i poddanym pod prawa własnej ewolucji. Będąc Umysłem Wszechświata może też doświadczać własnej emanacji poprzez inkarnowanie się w ciele fizycznym. W tej perspektywie każdy człowiek byłby cząstką jedynego Boskiego umysłu doświadczającą określonego fragmentu Boskiej rzeczywistości. W konsekwencji jest to zakwestionowanie realnego istnienia ludzkiego ja, naszej tożsamości, prawdziwej, choć zależnej w swym istnieniu od Absolutu. Uzyskanie boskości w takiej perspektywie oznacza śmierć własnego ja poprzez uświadomienie sobie bycia cząstką boskiego umysłu i konieczność wyjścia z iluzji bycia kimś odrębnym w relacji z kimś drugim. Emanacyjny system jest bowiem w istocie rzeczy systemem magicznym, w którym moc oddziaływania na osoby i rzeczy związana jest właśnie z panteistyczną wizją świata, w którym wszystko jest powiązane ze wszystkim, a odkrycie tych, na ogół niewidzialnych, powiązań stanowi podstawę wiedzy magicznej pozwalającej kontrolować i manipulować człowiekowi otaczającą

$11 \quad$ „Dochodzimy tu do momentu kluczowego, gdy fizyka traktuje o założeniach zbliżonych raczej do kosmologii i teologii wielkich religii Wschodu, które jednak coraz wyraźniej dominują także w nowożytnej tradycji ezoterycznej Zachodu. Zgodnie z owymi supozycjami praźródłem wszechświata jest Umysł uniwersalny, Boska praprzyczyna, z której wylewa się ocean inteligencji”. J. Ries, New Age e reincarnazione, [w:] Religioni e sette nel mondo 5, New Age 1, Rivista trimestrale di cultura religiosa, Marzo 1996, Anno 2, Numero 1, Bologna, (ss. 45-56). 
nas rzeczywistość. Jeżeli więc człowiek jest cząstką Boskiego umysłu, to zasadą jego rozwoju nie jest dojrzewanie w miłości, doskonałość duszy czy rozwój fizyczny, ale transformacja świadomości. W New Age nie chodzi tu o kolejną inkarnację zgodną z prawem karmy, ale o ewolucyjny rozwój człowieka w jego dążeniu do coraz wyższych wymiarów rzeczywistości. Moglibyśmy powiedzieć, że na miejsce wschodniej iluzji na Zachodzie wprowadzono termin Matrix. Człowiek może się z niego uwolnić tylko poprzez przejście na wyższy poziom świadomości i na tym generalnie opiera się podstawowe założenie Nowej Ery jak również podstawowe techniki rozwoju umysłu. W wierze chrześcijańskiej poznanie jest sprawą używania rozumu i jego rozwoju, który jednak jest ograniczony z natury. Potrzeba jest poznania wiary, która należy do porządku nadprzyrodzonego. Natomiast w rozumieniu wschodnim człowiek jako cząstka boskiego umysłu jest jako taki nieograniczony będąc częścią wszystkiego, musi jedynie wyjść z iluzji własnego ograniczonego ja, które uznał za realne, a które nie pozwala mu wyjść poza granice jego ograniczonego poznania. $\mathrm{Na}$ tej podstawie rodzi się na Zachodzie idea Potencjału ludzkiego umysłu i jego nieograniczonych możliwości oraz wiele technik rozwoju umysłu na bazie tej idei powstałych. Idea Potencjału ludzkiego umysłu stoi w oczywistej opozycji $z$ wiarą i zaciera realną granicę pomiędzy naturalnymi właściwościami człowieka a tym, co nadprzyrodzone.

\section{Psychologia ezoteryczna}

Zarówno starożytna koncepcja Umysłu Wszechświata właściwa systemom religijnym Wschodu jak i współczesna koncepcja Potencjału ludzkiego umysłu na tamtej bazując stanowią w istocie formy gnozy, czyli zbawczej rzeczywistości poznania. Człowiek doświadcza swojej boskości nie poprzez doskonalenie się moralne i miłość bliźniego, ale poprzez oświecenie. Nie mówi się zatem w gnozie o grzechu, ale o błędzie. Również idea miłosierdzia związana jest ściśle $z$ faktem oświecenia, a więc wiąże się bardziej ze stanem umysłu niż z otwartością serca. Jest więc związana z elitaryzmem, co najlepiej uwidacznia się w filantropii masońskiej. Szczególną formę gnozy stanowi dziś tzw. psychologia ezoteryczna, która bazuje w swych założeniach na antropologii Wschodu, kabalistycznej i teozoficznej. Rozwinęła się ona szczególnie w praktykach New Age, które zasymilowały wschodnią myśl religijną poprzez zastosowanie rozwijającej się na Zachodzie psychologii wraz ze swoją terminologią i metodą naukową. Psychologia ezoteryczna stanowi jaskrawy przykład pomieszania naukowej wizji świata i człowieka $z$ wizją systemów religijnych Wschodu, właściwy dla całego 
światopoglądu New Age $^{12}$. Tego typu psychologie i terapie przez nie stosowane przeniknęły dziś głęboko środowiska akademickie, medyczne, a przede wszystkim kulturę Zachodu dając szerokie przyzwolenie społeczne. Staje się dziś tym samym coraz bardziej wyraźną alternatywą dla kultury chrześcijańskiej i jej antropologii. Coraz więcej ludzi korzysta z niej nie tylko dla odzyskania równowagi psychicznej, ale zajmuje ona w ich życiu miejsce wiary stając się tym samym substytutem religijności.

\section{Carl Gustav Jung „ojcem” Nowej Ery}

Początki psychologii ezoterycznej należy wiązać z postacią Carla Gustava Junga, którego Papieski Dokument na temat New Age z 2003 roku określa mianem ojca Nowej Ery. Jest to znamienne, gdyż podkreśla fakt, iż „duchowość” Nowej Ery od samego początku ma ścisły związek z terminologią, metodologią oraz praktykami terapii psychologicznej ${ }^{13}$. W istocie jest ona nową formą gnozy i ma swoje korzenie w założeniach wielkich systemów religijnych Wschodu. Gustav Jung napisał w swojej książce o znamiennym tytule Podróż na Wschód, iż jego intencją jest „stworzyć na gruzach chrześcijaństwa Zachodnią Jogę”14, czym w rzeczywistości jest jego Psychologia Głębi. Ego czy „ja” racjonalne, o którym mówi, to nic innego jak iluzoryczna tożsamość w religiach Wschodu, zapomnienie o fakcie bycia cząstką boskiej świadomości, a nie realnym odrębnym bytem. Nieświadomość indywidualna byłaby w tej teorii właśnie tą cząstką boskiej świadomości, która poprzez wtopienie się w nieświadomość zbiorową, uzyskiwałaby dostęp do Umysłu Wszechświata, który w tej perspektywie byłby sumą indywidualnych tożsamości. Typowe dla gnozy oświecenie polegałoby na wyjściu poza iluzję własnego ja w celu odkrycia swojej prawdziwej tożsamości

12 „Decydującą rolę w upowszechnieniu owych pojęć w kręgu kultury europejskiej odegrała jednak psychologia ezoteryczna, której pionierem jest bez wątpienia C. G. Jung. Psychologia ta pozwoliła Ruchowi Nowej Ery opisać doświadczenie «ekspansji świadomości» jako deifikację ludzkiego «ja» na podobieństwo doświadczenia mistycznego wielkich religii Wschodu. Tym bowiem, co wydaje się szczególnie fascynować adeptów Nowej Ery w mistycyzmie Wschodu, uważa D. Hunt, jest odkrycie przestrzeni psychicznej, w której zaciera się granica pomiędzy naszym «ja» a Bogiem”. D. Hunt, Ameryka. Nowy uczeń czarnoksiężika, Warszawa $1992^{2}$, s. 226.

13 „Jung nie tylko spsychologizował ezoteryzm, ale także zsakralizował psychologię, przez wprowadzenie do niej elementów ezoterycznych spekulacji. Rezultatem tego była pewna ilość teorii, które pozwoliły ludziom mówić o Bogu, mając na myśli ich własną psychikę, i mówić o swojej własnej psychice, myśląc w rzeczywistości o boskości”. Papieska Rada Kultury, Papieska Rada ds. Dialogu Międzyreligijnego, Jezus Chrystus dawcą wody żywej. Chrześcijańska refleksja na temat „New Age”, 2.3.2 Podstawowy model myśli New Age (Roma, 3 luty 2003), [w:] EV 22, 41-166.

14 Por. C. G. Jung, Podróż na Wschód, Kraków 1989¹, s. 102-103. 
a jednocześnie Boskości. Jest to więc zupełnie nowa forma transcendencji, w której człowiek nie potrzebuje łaski, by przekroczyć samego siebie i wejść w relację z Absolutem, ale może za pomocą odpowiednich technik, metod czy terapii sam przekroczyć samego siebie, transcendować poprzez uświadomienie sobie bycia częścią Absolutu. Ta wizja człowieka wpisuje się ponadto w system reinkarnacji, czego sztandarowym przykładem były bardzo popularne w swoim czasie książki Życie po życiu i Życie przed życiem Raymonda Moody.

\section{Relatywizm poznawczy i moralny}

Będąc formą gnozy, New Age nie uznaje istnienia Prawdy obiektywnej czy objawionej w naszym rozumieniu. Skoro bowiem Bóg nie istnieje poza światem, a Jego świadomość poza ludzkim umysłem, to poznanie prawdy i prawa jest sprawą czysto subiektywną uzależnioną od stopnia oświecenia danej osoby ${ }^{15}$. Żaden system w tej perspektywie nie może uzurpować sobie prawa do postrzegania siebie jako jedynego prawdziwego, stąd rodzi się znana nam zasada, że wszystkie drogi prowadzą do Boga. Faktycznie możemy powiedzieć, że ilu jest ludzi, tyle jest form poznania Boga i tyleż dróg do Niego prowadzących. Jest to zatem forma gnozy propagująca skrajny indywidualizm i relatywizm zarówno poznawczy jak i w konsekwencji moralny. Mając bowiem prawo do własnej prawdy, mam też prawo do ustalania własnych zasad w oparciu o tak poznaną prawdę ${ }^{16}$. Każdy więc osąd czy próba dostrzegania lepszej czy gorszej prawdy staje się wyrazem nietolerancji i poczucia wyższości. To zaś obok tolerancji prowadzi do demokracji w wierze, która wyraża się w dialogu międzyreligijnym i w kompromisie, czyli w konieczności pogodzenia wielu, nawet bardzo różniących się od siebie, prawd i zasad moralnych. Tu rodzi się poprawność polityczna, która zmusza także wielu ludzi wierzących do wypierania się bądź przemilczania własnej wiary i przekonań. Jest to zatem nowa forma znanego już w historii rzymskiego Panteonu pod nowymi auspicjami ${ }^{17}$. Dlatego w Ruchu

15 W swojej książce Psychologia i religia Jung wnioskuje, w zgodzie z poglądami adeptów Nowej Ery, że bóstwo nie znajduje się wcale, jak myślą chrześcijanie, poza człowiekiem, lecz przeciwnie, w nim samym. Por. C. G. Jung, Psychologia i religia, Warszawa 1995', s. 76 .

16 „Ludzie, po spożyciu jabłka z drzewa poznania dobra i zła, muszą wyrzec się świadomości Raju. Od tego momentu bowiem muszą uczyć się myśleć autonomicznie i sami decydować o tym, co jest etycznie i moralnie słuszne jako korzystne dla życia, a co powoduje zniszczenie życia”. M. Pogačnik, La Forza di Cristo e il Ritorno della Dea, Collana: Il sentiero magico, Diegaro di Cesena 2003', s. 165.

17 „Za niewiele wieków nie będzie już więcej wierzeń sekciarskich wielkich religii ludzkości [...] «ja wyleję mego ducha na wszelkie ciało», mówi prorok Joel. «Zaprawdę mówię wam... wy będziecie czynić dzieła większe niż te», obiecuje Jezus. Ale to może wydarzyć się tylko 
New Age możemy znaleźć wszystko, łącznie z heretycką myślą chrześcijańską, $z$ wyjątkiem ortodoksyjnej wiary opartej na przyjęciu Absolutnej Prawdy Objawionej i Obiektywnego niezmiennego Prawa nadanego przez Osobowego Boskiego Prawodawcę. Tak pojęta Prawda i tak rozumiane Prawo jest dziśs prześladowane za nietolerancję i mówienie językiem nienawiści. To dlatego Pan Jezus, świadom, że jest dla wielu kamieniem obrazy powiedział, że Mnie prześladowali i was będą prześladować, za to, iż ośmielił siebie określić jako Jedyną Drogę, Prawdę i Życie. Wyniósł się w ten sposób ponad wszystkich bogów i ponad ludzką pychę, która w gnozie znalazła drogę do samozbawienia i samoubóstwienia w buncie przeciwko Bogu Stwórcy i Jego odwiecznemu Prawu.

\section{Zakończenie}

Postawienie w centrum wszechświata człowieka na miejsce Boga wyklucza nadprzyrodzoność, a jeśli nawet nie, to odmawia realnego wpływu na życie człowieka i społeczności ludzkiej. Człowiek żyje wtedy bez Boga lub obok Boga, znajdując ewentualnie różne substytuty nadprzyrodzoności, w których bóstwo jest bezosobowe, zależne od woli człowieka i nienarzucające Prawa, które daje człowiekowi i od człowieka egzekwuje Bóg Stwórca. Szczególnym typem transcendencji jest ten reprezentowany przez wielkie systemy religijne Wschodu, przeszczepiony na grunt Zachodu poprzez psychologię, gnozę, teorie paranaukowe, różnorodne metody medytacji i kontroli umysłu. Jest to wizja panteistyczna i monistyczna, w której nie istnieje realna różnica pomiędzy duchem i materią, pomiędzy stworzeniem a jego Stwórcą. Człowiek bowiem choć nie jest bogiem $w$ tej wizji, to jest $z$ natury boski i transcenduje siebie poprzez wyjście poza własne ja, transformację własnej świadomości, łączność z wszechobecną boską energią, eonami bóstwa. Jest to nadprzyrodzoność iluzoryczna, niewymagająca łaski jako niezasłużonego i nieosiągalnego o własnych siłach daru uczestnictwa w życiu Bożym. Nie wymaga przyjęcia krzyża lecz oświecenia umysłu i przełamania prawa karmicznego. Jedno i drugie jest wynikiem wysiłku człowieka, a więc jest formą gnozy i samozbawienia. Jest wyrazem ludzkiej pychy, która od zawsze pragnęła wynieść się ponad Boga i zająć Jego miejsce. Dla wielu jednak jest ona alternatywą w świecie, w którym zanika poczucie sacrum, jest wyraźny kryzys wiary, autorytetów i instytucji także religijnych. Jest więc również wyrazem zagubienia, poszukiwania wyższego celu i sensu życia, którego nie może odnaleźć już gdzie indziej, jest w końcu kryzysem ewangelizacji Kościoła, który ma wyraźną trudność w dotarciu dziś nie tyle

kiedy świat powróci na łono wielkiej religii przeszłości». H. P. Blavatsky, Iside Svelata, vol. II, s. 606. 
do głębin afrykańskiego buszu, co raczej na pustynię duchową wielkich miast zachodniego świata i jego dekadenckiej kultury.

Słowa kluczowe: Bóg, wieczność, nadprzyrodzony, duchowość, medytacja, Boska energia, gnoza, ewolucja, stworzenie, emanacja, życie wieczne, panteizm, transcendentny, prawo karmy, iluzja, psychologia ezoteryczna, bioterapia, transformacja świadomości, Absolut, reinkarnacja, Umysł wszechświata, relatywizm.

\section{Bibliografia:}

1. Blavatsky H. P., Iside Svelata. Chiave dei misteri della scienza e della teologia antiche e moderne, vol. I: Scienza, Milano 20003.

2. Capra F., Il Punto di Svolta, Milano 1984.

3. Conte di Saint-Germain, Io Sono, L'Età dell'Acquario, 2001'1, maj 2006.

4. Drago F., Vivere New Age, Milano $1998^{1}$.

5. Guerra M., Satanizm i lucyferyzm jako alternatywna i magiczna forma religijności naszych czasów, [w:] Teologia o Szatanie, Międzynarodowe sympozjum odbyte na Katolickim Uniwersytecie Lubelskim w 2000, K. Góźdź (red.), Lublin 2000.

6. Hunt D., Ameryka. Nowy uczeń czarnoksiężika, Warszawa 1992².

7. Introvigne M., Il cappello del Mago, Milano 2003.

8. Jung C. G., Podróż na Wschód, Kraków 1989¹.

9. Papieska Rada Kultury, Papieska Rada ds. dialogu Międzyreligijnego, Jezus Chrystus dawca wody żywej. Chrześcijanska refleksja na temat „New Age”, 2.3.2 Podstawowy model myśli New Age (Roma, 3 luty 2003), w: EV 22, 41-166.

10. Pigani E., Channel. I medium della Nuova Era, Roma 1993.

11. Pogačnik M., La Forza di Cristo e il Ritorno della Dea, Collana: Il sentiero magico, Diegaro di Cesena $2003^{1}$.

12. Ries J., New Age e reincarnazione, [w:] Religioni e sette nel mondo 5, New Age 1, Rivista trimestrale di cultura religiosa, Marzo 1996, Anno 2, Numero 1, Bologna.

13. Terrin A. N., New Age. La religiosità del postmoderno, Bologna 1993¹ $1997^{2}$.

14. Jung C. G., Psychologia i religia, Warszawa $1995^{1}$.

15. Price J. R., Il Codice di Gesù. Un'esperienza mistica rivela un nuovo paradigma per la vita, Diegaro di Cesena 2001. 